\title{
Adrenergic activity of the oviduct of the domestic fowl
}

\author{
O. P. Verma, B. K. Prasad and A. Yancey \\ Laboratory for Reproductive Physiology, School of Veterinary Medicine, \\ Tuskegee Institute, Alabama 36088, U.S.A.
}

\begin{abstract}
Summary. The adrenergic activity of the domestic hen was investigated. Administration of noradrenaline to laying hens at dose levels of $3 \cdot 5,7 \cdot 0$ and $14.0 \mu \mathrm{g} / \mathrm{kg}$ produced an increase in the magnal pressure, and a simultaneous decrease in the uterine pressure. Similar doses given to ovariectomized hens caused an inhibition of activity in both segments. Strips of tissues from the vagina and the uterovaginal junction of laying hens were exposed in vitro to noradrenaline at concentrations of $1.5 \times 10^{-6}$ and $2.9 \times 10^{-6} \mathrm{M}$. The vaginal strips reacted with a sharp increase in tension, while the uterovaginal preparations showed a more gradual and prolonged response. It is suggested that the beta inhibitory activity of the uterus and the alpha excitatory activity of the rest of the oviduct are involved in the regulation of ovum transport.
\end{abstract}

\section{Introduction}

In mammals, adrenergic nerves may be involved in the transport of gametes in the female reproductive tract (Marshall, 1973). The smooth muscles of the uterus and the oviduct contain alpha and beta adrenergic receptocytes and the degree of adrenoceptor stimulation depends upon the levels of circulating oestrogen or progesterone (Howe \& Black, 1973). Oestrogen increases the alpha receptor sensitivity, while progesterone enhances the beta sensitivity (Coutinho, Demattos \& DaSilva, 1971).

There have been limited studies on the avian oviduct, and none on the uterovaginal junction. The oviduct of the actively laying domestic hen exhibits a differential response to noradrenaline, being stimulated at the proximal end (infundibulum, magnum and isthmus) and inhibited at the uterine end (Verma \& Walker, 1974). Vaginal, but not uterine, strips from laying hens are stimulated by adrenaline when tested in vitro (Sykes, 1955) and non-laying hens with low blood oestrogen levels can be similarly stimulated after treatment with oestrogen (Prasad, Davis \& Dale, 1964).

The present studies were conducted (1) to determine the adrenergic activity of the uterovaginal junction and vagina in laying hens, and (2) to investigate the adrenergic response of the magnum and uterus in ovariectomized hens.

\section{Materials and Methods}

Twenty-two single-comb White Leghorn hens in their first year of production were maintained in individual cages and allowed free access to feed (layer's mash) and water. For maximum reproductive efficiency (see Sturkie, 1970), artificial light was provided continuously beginning 1 week before the start of the experiment.

\section{Experiment 1}

The adrenergic activity of the uterovaginal junction and the vagina of actively laying hens was studied in vitro. The hens were killed by dislocation of the atlas and the oviduct was removed and placed immediately in Kreb's-Ringer bicarbonate solution of the following composition (mM): $\mathrm{NaCl}$, $126.5 ; \mathrm{KCl}, 4 \cdot 7 ; \mathrm{CaCl}_{2}, 2 \cdot 5 ; \mathrm{KH}_{2} \mathrm{PO}_{4}, 1 \cdot 2 ; \mathrm{NaHCO}_{3}, 17 \cdot 1$; and $1 \mathrm{mg}$ glucose/ml. Transverse strips ( $3.0 \mathrm{~cm}$ long, $0.5-1.0 \mathrm{~cm}$ wide) from the uterovaginal junction and the vagina were suspended in a 
water-jacketed organ bath of 10-ml capacity, containing Kreb's-Ringer bicarbonate of the above composition and maintained at $41{ }^{\circ} \mathrm{C}$. A mixture of $95 \% \mathrm{O}_{2}$ and $5 \% \mathrm{CO}_{2}$ was gently bubbled through the bath during the experiment. One end of the tissue strip was anchored to a hook at the bottom of the bath and the free end was attached to force transducer (Myograph A: Narco Biosystem, Houston, U.S.A.). The signals from this transducer were conditioned by a channel amplifier (Type 7070: Narco Biosystem) in series with 6-channel Physiograph. The system was calibrated in such a way that $0.5 \mathrm{~g}$ tension applied at the transducer gave a pen deflection of $5.0 \mathrm{~cm}$. The strips were allowed to equilibrate in the bath fluid for 25-30 min before the various drugs wereadded. Noradrenaline (Levarterenol Bitartrate: Winthrop Laboratories, New York, U.S.A.) was added in constant volume (1.0 ml) but in amounts sufficient to give a concentration of $1.5 \times 10^{-6} \mathrm{M}$ followed by $2.9 \times 10^{-6} \mathrm{M}$ in the bathing medium. The tissues were washed twice before using the next drug. After determination of the response to noradrenaline, phenoxybenzamine hydrochloride (Dibenzyline: Smith, Kline \& French, Philadelphia, U.S.A.) was added at a concentration of $3.3 \times 10^{-4} \mathrm{M}$ to block the alpha adrenocytes. After washing, the tissue response to noradrenaline was again checked at $1.5 \times 10^{-6} \mathrm{M}$.

\section{Experiment 2}

The left ovary was surgically removed from the hens which were allowed to recover 7-10 days before investigation of the activity of the magnum and isthmus in vivo. The motility was recorded by the technique described previously (Verma \& Walker, 1974). The hens were anaesthetized with $1 \cdot 2 \mathrm{~g}$ ethyl carbamate (urethane) and at laparotomy one sponge-tipped catheter was inserted into the magnum and one into the uterus. The free end of each catheter was connected to two separate pressure transducers (Model 1280C: Hewlett \& Packard, Waltham, Massachusetts, U.S.A.) in series with precalibrated 8-channel recorder (Sanborn Model 350: Hewlett \& Packard). Control recordings were taken for 30-40 min before administering the drug. A cannula with a stopcock was introduced into the saphenous vein for injection of noradrenaline in increasing doses of $3 \cdot 5,7 \cdot 0$ and $14 \cdot 0 \mu \mathrm{g} / \mathrm{kg}$. The interval between doses was $25-30 \mathrm{~min}$ by which time the contractions had returned to the preinjection level. Because the contractions in the ovariectomized hens were usually weak and irregular (or even arrested) after noradrenaline administration, the blockade effect of phenoxybenzamine could not be studied in this experiment.

\section{Assessment of tracings and statistical analysis}

The pressure cycles from the tracings in Exp. 2 were assessed from recordings of at least 10-min duration by their amplitude ( $\mathrm{mmHg}$ ), frequency (contractions/min) and activity index (amplitude $x$ frequency). The response of the drug was evaluated by the pressure changes and the duration of response. In Exp. 1, the spontaneous contractions and the responses to the drugs were similarly evaluated except that the amplitude of contraction was expressed in terms of pen defiection ( $\mathrm{mm})$. The significance of the differences between the means was tested by analysis of variance (Steel \& Torrie, 1960).

\section{Results}

\section{Experiment 1}

The strips of the uterovaginal junction and vagina exhibited spontaneous activity and were stimulated by noradrenaline at both doses (Table 1, Text-fig. 1). The uterovaginal junction showed a gradual increase in tonus, reaching a peak in 2-3 min and declining to the preaddition level in 5-7 min. The activity of the vaginal strips increased sharply but also returned to the preaddition level in 2-3 $\min$. After the use of phenoxybenzamine, the strips from both tissues responded to noradrenaline as they had before, amplitude $(\mathrm{mm})$ and duration $(\mathrm{min})$ being, respectively, $23.0 \pm 3.4$ (S.E.M.) and $6 \cdot 7 \pm 0.7$ for uterovaginal junction and $20 \cdot 1 \pm 5 \cdot 1$ and $3.9 \pm 0.4$ for vagina. 
Table 1. The response (mean \pm S.E.M.) of vaginal and uterovaginal junction strips of the hen to noradrenaline in vitro

\begin{tabular}{lcccc}
\hline Segment & $\begin{array}{c}\text { Conc. } \\
\text { noradrenaline (M) }\end{array}$ & $\begin{array}{c}\text { No. of hens } \\
\text { responding/no. tested }\end{array}$ & Amplitude (mm) & $\begin{array}{c}\text { Duration of } \\
\text { response (min) }\end{array}$ \\
\hline $\begin{array}{l}\text { Uterovaginal } \\
\text { junction }\end{array}$ & 0 & & & \\
& $1.5 \times 10^{-6}$ & $0 / 6$ & $4.5 \pm 0.9$ & - \\
Vagina & $2.9 \times 10^{-6}$ & $4 / 5$ & $11.1 \pm 2.2$ & $5.5 \pm 0.4$ \\
& 0 & $4 / 6$ & $23.0 \pm 3.4$ & $6.7 \pm 0.7$ \\
& $1.5 \times 10^{-6}$ & $0 / 6$ & $2.9 \pm 0.3$ & - \\
& $2.9 \times 10^{-6}$ & $4 / 6$ & $16.1 \pm 2.9$ & $2.3 \pm 0.6$ \\
& & $4 / 6$ & $20.1 \pm 5.1$ & $3.9 \pm 0.4$ \\
\hline
\end{tabular}

(a)

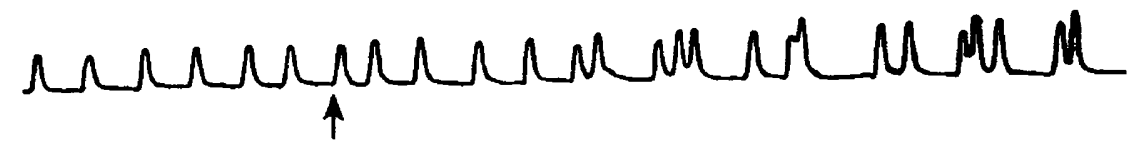

(b)

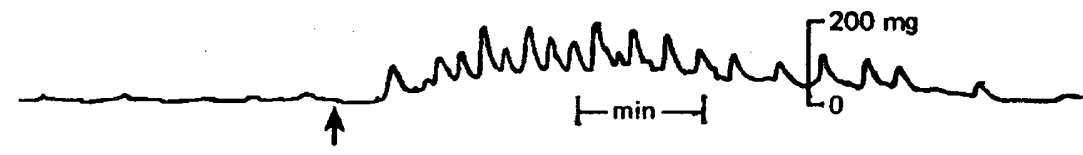

Text-fig. 1. The response in vitro of strips of (a) the uterovaginal junction and (b) the vagina of hens treated (arrow) with $2.9 \times 10^{-6} \mathrm{M}$-noradrenaline. The calibration is the same for both traces.

\section{Experiment 2}

After ovariectomy, the spontaneous activity of the magnum and the uterus was depressed (Table 2). Administration of noradrenaline produced an increase in the magnal pressure and a simultaneous decrease in the uterine pressure of intact hens, but not in the ovariectomized hens, in which these responses were inhibited (Table 3, Text-fig. 2). The two doses of noradrenaline sometimes caused complete cessation of the uterine contractions in ovariectomized hens while the magnal contractions were arrested only briefly; the contractions then usually became weak and irregular.

Table 2. Activity in vivo of the magnum and isthmus of intact laying and ovariectomized hens (5/group, mean \pm S.E.M.)

\begin{tabular}{|c|c|c|c|c|c|}
\hline Segment & Group & & $\begin{array}{l}\text { Luminal pressure } \\
\text { (amplitude, } \mathrm{mmHg} \text { ) }\end{array}$ & $\begin{array}{c}\text { Frequency } \\
\text { (contractions/min) }\end{array}$ & $\begin{array}{r}\text { Activity index } \\
\text { (amplitude } x \\
\text { frequency) }\end{array}$ \\
\hline Magnum & $\begin{array}{l}\text { Intact } \\
\text { Ovariectomized }\end{array}$ & F value & $\begin{array}{l}6.2 \pm 0.7 \\
4.5 \pm 0.6 \\
3.09\end{array}$ & $\begin{array}{l}5.9 \pm 0.4 \\
4.7 \pm 0.4 \\
4.05\end{array}$ & $\begin{array}{c}36 \cdot 7 \pm 5 \cdot 4 \\
20 \cdot 3 \pm 3 \cdot 3 \\
6 \cdot 66^{* *}\end{array}$ \\
\hline Uterus & $\begin{array}{l}\text { Intact } \\
\text { Ovariectomized }\end{array}$ & F value & $\begin{array}{l}6 \cdot 5 \pm 1 \cdot 0 \\
4 \cdot 8 \pm 0 \cdot 4 \\
4 \cdot 46\end{array}$ & $\begin{array}{l}8.1 \pm 0.8 \\
4.2 \pm 0.5 \\
17.73^{* *}\end{array}$ & $\begin{array}{l}51.7 \pm 5.0 \\
19.5 \pm 1.8 \\
35.72^{*}\end{array}$ \\
\hline
\end{tabular}

Significantly different from values for intact birds; ${ }^{*} P<0.05, * * P<0.01$. 
Table 3. Response (mean \pm S.E.M.) of the avian oviduct in vivo to noradrenaline after ovariectomy

\begin{tabular}{|c|c|c|c|c|c|c|c|}
\hline \multirow[b]{2}{*}{ Segment } & \multirow[b]{2}{*}{$\begin{array}{c}\text { Dose of } \\
\text { noradrenaline } \\
(\mu \mathrm{g} / \mathrm{kg})\end{array}$} & \multicolumn{3}{|c|}{ Intact hens } & \multicolumn{3}{|c|}{ Ovariectomized hens } \\
\hline & & No. $\dagger$ & $\begin{array}{l}\text { Luminal } \\
\text { pressure } \\
\text { (mmHg) }\end{array}$ & $\begin{array}{l}\text { Duration of } \\
\text { response } \\
\text { (min) }\end{array}$ & No.† & $\begin{array}{l}\text { Luminal } \\
\text { pressure } \\
(\mathrm{mmHg})\end{array}$ & $\begin{array}{c}\text { Duration of } \\
\text { response } \\
\text { (min) }\end{array}$ \\
\hline \multirow[t]{4}{*}{ Magnum } & 0 & $0 / 6$ & $6.2 \pm 0.7$ & & $0 / 5$ & $6.5 \pm 1.0$ & \\
\hline & 3.5 & $6 / 6$ & $19.8 \pm 0.6$ & $1 \cdot 1 \pm 0 \cdot 1^{*}$ & $5 / 5$ & $0.6 \pm 0.6$ & $1.4 \pm 0.2$ \\
\hline & $7 \cdot 0$ & $6 / 6$ & $20.3 \pm 0.8$ & $1.1 \pm 0.1^{*}$ & $5 / 5$ & $\overline{0}$ & $3.2 \pm 0.2$ \\
\hline & $14 \cdot 0$ & $6 / 6$ & $17 \cdot 8 \pm 0.5$ & $1 \cdot 5 \pm 0.1^{*}$ & $5 / 5$ & 0 & $3.6 \pm 0.1$ \\
\hline \multirow[t]{4}{*}{ Uterus } & 0 & $0 / 6$ & $6 \cdot 5 \pm 1 \cdot 0$ & & $0 / 5$ & $1.8 \pm 0.4$ & \\
\hline & $3 \cdot 5$ & $5 / 6$ & $2 \cdot 1 \pm 2 \cdot 2$ & $1 \cdot 3 \pm 0 \cdot 1$ & $4 / 5$ & 0 & $1.2 \pm 0.1$ \\
\hline & $7 \cdot 0$ & $5 / 6$ & $1.8 \pm 0.3$ & $2.4 \pm 0.2$ & $4 / 5$ & 0 & $2.5 \pm 0.2$ \\
\hline & $14 \cdot 0$ & $5 / 6$ & $1 \cdot 0 \pm 0.1$ & $3.2 \pm 0.2$ & $4 / 5$ & 0 & $3.8 \pm 0.2$ \\
\hline
\end{tabular}

* These values were significantly different $(P<0.01)$ from those found in ovariectomized birds.

$\uparrow$ No. of hens responding/no. tested.

(a)

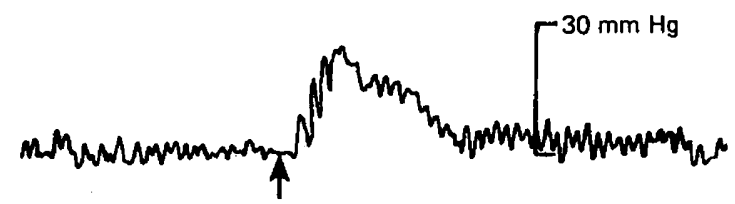

(b)

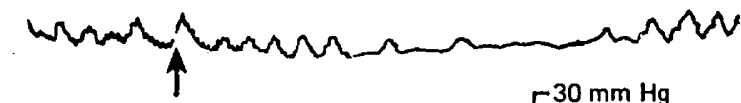

(c)

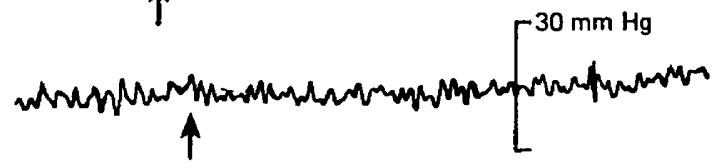

(d)

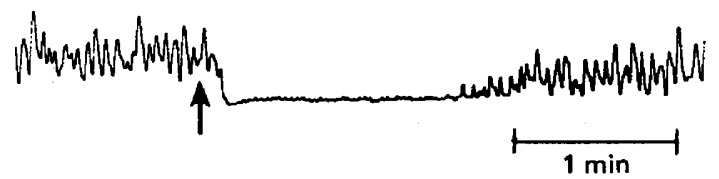

Text-fig. 2. The response in vivo of the magnum (a, b) and isthmus (c, d) of intact (a, c) and ovariectomized $(b, d)$ hens treated with $3 \cdot 5 \mu \mathrm{g}$ noradrenaline $/ \mathrm{kg}$.

\section{Discussion}

The present results and those reported earlier (Verma \& Walker, 1974) indicate that the adrenergic system is involved in the mechanism controlling the muscular activity of the avian oviduct. The response of the uterovaginal junction and vagina to noradrenaline could not have been due to the excitation of adrenergic receptors, because the specific $\alpha$-receptor blocker was ineffective in the present studies (Table 1). A beta-excitatory effect of noradrenaline was not investigated in the present experiments, but Verma \& Walker (1974) demonstrated that contractions in the avian uterus were inhibited by noradrenaline and isoproterenol and that this inhibitory response could be blocked by propranalol but not by phenoxybenzamine. It is therefore probable that the uterus of the hen is served by $\beta$-inhibitory receptors. If noradrenaline does not initiate contractions of hen's uterus, there 
must be another cause of the contractions associated with ovipositions. It is probable that oxytocin and/or prostaglandins are involved (Sturkie, 1970; Verma, Prasad \& Slaughter, 1976). The avian uterus retains the egg for $20-22 \mathrm{~h}$ and during this time the shell is deposited (Sturkie, 1970). This retention is probably mediated through the $\beta$-receptors of the adrenergic nervous system (Verma \& Walker, 1974). The relatively rapid passage of the egg through the proximal segments of the oviduct (infundibulum, magnum and isthmus) in 4-6 h could be due to excitation of the $\alpha$-receptors. The similar excitatory activity of the uterovaginal junction and the vagina observed in the present studies could also explain the uninterrupted passage of the egg through these segments at the time of oviposition. The regulation of ovum transport by adrenergic neurones has been reported for the rabbit (Brundin, 1969), in which doses of oestrogen or progesterone that retard or accelerate ovum transport were also found to alter the tissue content of noradrenaline (Bodkhe \& Harper, 1972). The noradrenaline content of the avian oviduct is increased significantly during the active laying period and falls to a low level when the oviduct becomes inactive during the non-laying phase (Ransome, Sadiku \& Verma, 1976).

Adrenergic nerves have been implicated in other processes of reproduction in mammals, and they have been reported to be involved in the process of ovulation (Bahr, Kao \& Nalbandov, 1974). The domestic hen is able to store spermatozoa for prolonged periods in the sperm-host glands demonstrated in the uterovaginal junction area of chicken and turkey hens (Bobr, Lorenz \& Ogasawara, 1964; Verma \& Cherms, 1964), but the mechanism by which the spermatozoa are released from these glands is uncertain (Thibault, 1973): electron microscopic studies have failed to show the presence of myoepithelial cells around the sperm host-glands (Vankrey, Ogasawara \& Lorenz, 1967) and autonomic nerves are absent (Gilbert, Reynolds \& Lorenz, 1968). The stimulation of the uterovaginal junction by noradrenaline, as observed in the present studies, suggests that this neurotransmitter may cause release of spermatozoa from the host glands.

The weak and irregular activity recorded from the ovariectomized hens (Table 2) could have been caused by atrophy of the oviduct or by the lack of ovarian hormones (Coutinho \& DeMattos, 1968). Boling \& Blandau (1971) observed a depressed activity from the rabbit oviduct 84-161 days after ovariectomy, while Howe \& Black (1973) recorded increased activity after 21-28 days. The avian oviduct is known to regress rapidly at the onset of the inactive state. In birds, the right ovary, which is normally rudimentary has the ability to develop and produce sex hormones after the removal of the left ovary (Sturkie, 1965). No such ovarian development was observed in the present experiment in which the interval between ovariectomy and experiment was 7-10 days and a differential development of the right ovary can also therefore be excluded as a cause of the irregular activity. The ovariectomized hens showed not only a depressed magnal activity but also exhibited a 'reversed' response to noradrenaline when compared with that of laying hens (Table 3). Such a reversal of response to adrenaline has been found in the uteri of rats at mid-pregnancy (Tothill, Rathbone \& Willman, 1971).

Avian gonads are very sensitive to light; $14 \mathrm{~h}$ daylight or artificial light/day is generally considered sufficient for optimum gonadal stimulation. Sturkie (1970), however, indicates that egg production is significantly increased by providing continuous light. The mechanism of action of light on gonads is believed to be mediated via melatonin, which is highly localized in the pineal gland (Wurtman \& Cardinali, 1974). Exposure of hens to $14 \mathrm{~h}$ light/day increases the pineal weight and melatonin synthesis compared with the values in hens exposed to constant darkness, but any further increase in light (to $24 \mathrm{~h}$ ) does not appear to cause a significant change (Axelrod \& Wurtman, 1964). The provision of continuous light in the present experiments, therefore, probably did not affect melatonin synthesis, but could have produced excessive adrenal secretions. However, the design of the experiment, in which the tissue response to noradrenaline was compared with the spontaneous activity of the same tissue, allowed each animal to serve as its own control.

The investigation was supported by NIH Grant No. RR-08091, and by CSRS, U.S. Department of Agriculture, Grant No. 616-15-11. 


\section{References}

Axelrod, J. \& Wurtman, R.J. (1964) Melatonin synthesis in the hen pineal gland and its control of light. Nature, Lond. 201, 1134.

BAHR, J., KaO, L. \& Nalbandov, A.V. (1974) The role of catecholamines and nerves in ovulation. Biol. Reprod. 10, 273-290.

Bobr, L.W., Lorenz, F.W. \& Ogasawara, F.X. (1964) Distribution of spermatozoa in the oviduct and fertility in domestic birds. 1. Residence sites of spermatozoa in fowl oviduct. J. Reprod. Fert. 8, 3947.

BODKHE, R.R. \& HARPER, M.J.K. (1972) Changes in the amount of adrenergic neurotransmitter in the genital tract of untreated rabbits, and rabbits given reserpine or isoproniazid during the time of egg transport. Biol. Reprod. 6, 288-299.

Boling, J.L. \& Blandau, R.J. (1971) Egg transport through the ampullae of the oviducts of rabbits under various experimental conditions. Biol. Reprod. 4, $174-184$.

Brundin, J. (1969) Pharmacology of the oviduct. In The Mammalian Oviduct, Ch. 10, pp. 251-271. Eds E.S.E. Hafez \& R. J. Blandau. University of Chicago Press.

Coutrnho, E.M. \& DeMatros, C.E.R. (1968) Effects of estrogen on the motility of non-atrophic estrogen deficient rabbit uterus. Endocrinology 83, 422-432.

Coutinho, E.M., DeMattos, C.E.R. \& Dasilva, A.R. (1971) The effect of ovarian hormones on the adrenergic stimulation of the rabbit Fallopian tube. Fert. Steril. 22, 311-317.

Donoso, A.O., Bishop, W., Fawcett, C.P., Krulich, L. \& MCCANN, S.M. (1971) Effect of drugs that modify brain monoamine concentration on plasma gonadotrophin and prolactin levels in the rat. Endocrinology 89, 774-784.

Gilbert, A.B., ReYNOLds, M.E. \& LoRenz, F.W. (1968) Distribution of spermatozoa in the oviduct and fertility in domestic birds. VIII. Innervation and vascular supply of the uterovaginal sperm host glands of the domestic hen. J. Reprod. Fert. 17, 305-310.

Howe, G.R. \& BLACK, D.L. (1973) Autonomic nervous system and oviduct function in the rabbit. I. Hormones and contraction. J. Reprod. Fert. 33, 425-43C.
Marshall, J.M. (1973) Effect of catecholamines on the smooth muscle of the female reproductive tract. $A$. Rev. Pharmac. 13, 19-32.

Prasad, A., Davis, L.E. \& Dale, H.E. (1964) Adrenergic response of the avian uterus. Poultry Sci. 43, 192-196.

Ransome, B., SAdiku, A. \& Verma, O.P. (1976) Presence of norepinephrine in the avian oviduct. Proc. 4th St Xavier MBS Symposium, New Orleans pp. 152.

Steel, R.G.D. \& Torrie, J.H. (1960) Principles and Procedures of Statistics. McGraw Hill Book Co., New York.

Sturkie, P.D. (1965) Avian Physiology, 2nd edn, p. 575. Cornell University Press, Ithaca, New York.

Sturkie, P.D. (1970) Avian reproduction. In Dukes' Physiology of Domestic Animals, 8th edn. Ed. M. J. Swenson. Cornell University Press, Ithaca, New York.

SyKES, A.H. (1955) The effect of adrenaline on oviduct motility and egg production in fowl. Poultry Sci. 34, $622-628$.

Thibault, C. (1973) Sperm transport and storage in vertebrates. J. Reprod. Fert., Suppl. 18, 39-53.

Tothill, A., Rathbone, L. \& Willman, E. (1971) Relation between prostaglandin $E_{2}$ and adrenaline reversal in the rat uterus. Nature, Lond. 233, 56.

Vankrey, H.P., Ogasawara, F.X. \& Lorenz, F.W. (1967) Light and electron microscope studies of possible sperm gland emptying mechanism. Poultry Sci. 46, 69-72.

Verma, O.P. \& Cherms, F.L. (1964) Observations on the oviduct of turkeys. Avian Diseases 8, 19-26.

VERMA, O.P. \& WALKER, C.A. (1974) Adrenergic activity of the avian oviduct. Theriogenology 2, 47-61.

Verma, O.P., Prasad, B.K. \& Slaughter, J. (1976) Avian oviduct motility induced by prostaglandin $\mathrm{E}_{1}$. Prostaglandins 12, 217-227.

Wurtman, R.J. \& Cardinali, D.P. (1974) The pineal organ. In Textbook of Endocrinology, Sth edn, Ch. 13, pp. 835-838. Ed. R. H. Williams. W. B. Saunders \& Company, Philadelphia.

Received 18 May 1976 